\title{
Gender specific, worldwide picture of liver cancer: A special comparison with Pakistan
}

\author{
Muhammad Asad ${ }^{1}$, Iqra Rasool ${ }^{1}$, Saira Khan², Faiza Anum², Mushtaq A \\ Saleem ${ }^{1}$ and Shahid Raza ${ }^{2 *}$ \\ 1. Department of Biotechnology, University of central Punjab-Pakistan \\ 2. Department of ORIC, Lahore Garrison University, Lahore-Pakistan \\ *Corresponding author's email: dr.raza03@gmail.com
}

Citation

Muhammad Asad, Iqra Rasool, Saira Khan, Faiza Anum, Mushtaq A Saleem and Shahid Raza. Gender specific, worldwide picture of liver cancer: A special comparison with Pakistan. Pure and Applied Biology. Vol. 9, Issue 4, pp2403-2414. http://dx.doi.org/10.19045/bspab.2020.90255

\begin{tabular}{llll}
\hline Received: 01/02/2020 & Revised: 25/05/2020 & Accepted: 22/07/2020 & Online First: 24/07/2020 \\
\hline
\end{tabular}

\section{Abstract}

Present study performed was actually done for measuring cancer frequency in Liver, Occurrence as well as rate of death beside Hugh liquor intake plus various hazardous aspects (containing smoking, narcotics, hugh food sugar) between people of both genders globally in comparison to our state (Pakistan). Data was composed through review piece of writings informed via world health organization WHO (2012) Globocan as well as during 2013 Global illness load. Review writing was completed on frequency, occurrence as well as because of hepatic carcinoma happened in 2012 as well as 2012 of universal in association towards Pakistan. Hepatic carcinoma had additional incidence in males rather than females. Pakistan had hepatic carcinoma incidence $(13.1 \%)$ in males as well as (1.6\%) in females, that percentage was in use as of every additional carcinoma. Statistic methods applied to the current study were death pace, prevalence pace, age standardize rate (asr), modification in percentage, incidence in percentage as well as case control table. Present study, incidence of hepatic carcinoma was higher in males rather than females, mutually globally as well as Pakistan.

Keywords: Age standardize rate; Cancer; Hazardous; Hepatic carcinoma; Liquor; Occurrence; Statistic methods

\section{Introduction}

Hepatic carcinoma is the $6^{\text {th }}$ most basic most malignant growths $(6 \%)$ and the second one fundamental explanation of biting the dust from most tumors (9\%) [1, 2]. In 2012 it went off in 7,820 people and in 2015 finished in eight lac ten thousand and five hundred passing $[2,3]$. Two lac sixty three thousand passing from liver disease have been a direct result of hepatitis $\mathrm{B}$, one lac sixty seven thousand to hepatitis $\mathrm{C}$, and two lac forty five thousand to liquor in 2015 [3]. Higher paces of liver malignant growth happen in which $\mathrm{HBV}$ and HCV are ordinary, comprehensive of Asia and sub-Saharan Africa. Guys are more every now and again influenced with HCC than women [1]. Diagnosis is generally visit among those 55 to 65 years collectible [4]. Five years endurance costs are $18 \%$ within US [4]. The word hepatic has Greek origin "hepar", that signifies "liver" $[5,6]$. Greatest successive liver majority 
malignancies, representing around $75 \%$, all main hepatic diseases, is hepatocellular carcinoma (HCC) that is a disease molded with the guide of liver cells, alluded to as hepatocytes that become harmful. Another kind of most malignant growths framed through hepatocytes, liver blastoma, exclusively molded via method for juvenile hepatocytes [7]. An uncommon dangerous cancer growth so as to as often creates in adolescents, and records for around $1 \%$ of all malignant growths in kids and $79 \%$ of all main liver diseases underneath the age of fifteen. The majority hepatoblastomas structure in the finest probable flap [8].

\section{Liver}

\section{Anatomical examination}

Homo sapiens body's greatest organ that really has mass of around fifteen hundred grams, and is situated in the top legitimate niche of the stomach. Liver is painstakingly connected with the little gut, preparing the supplement advanced venous blood that come out from stomach related region. Practically blood which is making its entry in liver by means of the entryway tract begins through Gastrointestinal tract (GIT) not withstanding from the, pancreas, gallbladder plus spleen. Its biggest human body organ of weight around fifteen hundred grams, and is set inside the upper right niche of the belly. Practically blood making entry in liver through entryway region starts from the GIT just like through gallbladder, spleen as well as pancreas. Blood flow towards liver other than the first supply starts through liver course, spreading promptly through celiac trunk as well as downward artery. Venous blood supplies via portal vein in little pressure situation on way to liver, while liver arterial blood is of high-pressure.

1.3 Liver Cancer: It can be termed as hepatic cancer as well as primary hepatic cancer, is cancer whose origin is liver actually. The type of carcinoma that spread from other areas and come toward liver is called as liver metastasis. The main explanation regarding the organ most tumors is cirrhosis due to hepatitis B (HBV), hepatitis C (HCV), or else liquor, different reasons incorporate aflatoxin, non-alcoholic greasy hepatic ailment, as well as hepatic accidents. Analysis is done via various tests of blood as well as medical imaging through verification via biopsy of specific tissue [9].

\section{Sort of hepatic carcinoma}

Diverse kinds of hepatocytes in liver can shape a few kinds of threatening (carcinogenic) and considerate (non-harmful) tumors. Amiable liver tumors: Benign tumors now and then become enormous adequate to cause issues, yet they don't form into close by tissues or spread to removed pieces of the body. In the event that they should be taken care of, the patient can as a rule be restored with medical procedure. Types ensured Hemangioma, Hepatic adenoma, Focal nodular hyperplasia.

\section{Sorts of essential hepatic malignant growth}

Malignant growth which start in the liver is portrayed as essential liver disease. Essential liver malignancy has more than one kind.

\section{Hepatocellular carcinoma (hepatocellular malignant growth)}

It's among the across the board sort of liver cancers found in grown-ups. Hepatocellular malignancies (HCC) will have distinctive blast designs

- $\quad$ Some initiate the same as a solitary tumor to turn out to be bigger.

- The other appears initiating, similar numeral of minute tumor knobs all the way through liver, presently not just a solitary tumor. Normally people with cirrhosis have such cases (incessant liver harm) as well as very well-known example found within US.

Intrahepatic cholangiocarcinoma (bile conduit most tumors)

2 to $10 \%$ of malignant growths whose initiations are hepatic origin, termed as intrahepatic cholangio carcinomas. Such 
malignancies initiate inside hepatocytes which are involve in making lining of bile conduits, inside the largest gland. The majority cholangio carcinomas truly initiate inside bile conduits outside the liver.

Angiosarcoma as well as hemangiosarcoma

Uncommon diseases which start in cells coating hepatic veins. Individuals who've been presented to vinyl chloride or to thorium dioxide (Thorotrast) are substantially extra prone towards tumor growths. Development of such tumor growths are rapid. Chemotherapy as well as radiation treatment can likewise assist drowsy turmoil, yet such malignant growths be normally extremely intense for treatment [10].

\section{Hepatoblastoma}

An absolutely phenomenal sort of most diseases that creates in kids, for the most part in those more youthful than four years of age. The cells of hepatoblastoma are a lot of like fetal liver cells. Around two out of three kids having those tumors are dealt with effectively through careful treatment plus chemotherapy.

Secondary hepatic cancer (metastatic hepatic cancer)

More often than not when malignant growth seen inside the liver it didn't start there anyway has spread (metastasized) from somewhere else inside the body, which incorporate the pancreas, colon, stomach, bosom, or lung. Since such malignant growth has spread through unique (essential) site, it's miles an optional liver most diseases. Such growths are named as well as treated principally dependent on their essential site (wherein they began).

Hazard Factors: A hazard issue is whatever that influences your opportunity of getting a confusion, which incorporate most malignant growths. Various tumors have distinctive possibility components. Some possibility components, such as smoking, can be changed. Others, similar to an individual's age or hover of family members history, couldn't get varied $[11,12]$.

\section{Materials and methods}

Design

It's a review study.

\section{Study setting}

Study was carried out in Biostatistics department of Sheikh Fatima Institute of Nursing and Health Sciences, Sheikh Zayed Medical Complex Lahore.

\section{Study population}

Review study completed on incidence, happening as well as death because hepatic carcinoma took place in 2012 as well as 2013 of universal in contrast towards Pakistan.

\section{Inclusion criteria}

Every single one internet sources that provide information regarding hepatic carcinoma include male plus females.

\section{Exclusion criteria}

Each and every other than inclusion criterion will be disqualified.

\section{Sample size}

Facts arranged through four hepatic cancer findings on the way to examine global hepatic tumor portrait in contrast of Pakistan. Sample study

Sampling (2-stage) was done initially to segregate five continents into 4 divisions after that select diverse countries through every partition plus current method was done in 2 levels.

\section{Data collection}

Composed data was from the review articles informed from WHO in 2012 Globocan and in 2013 worldwide infection loads. Collected of data on age, gender specific liver cancer incidence, frequency, death as well as its hazardous parameters (comprise of Alcohol, Smoking, Drug and High sugar diet).

\section{Data analysis}

Descriptive analysis

For the analysis of data following statistical tools and graphs were used

\section{Statistical tools}

- Death rate 


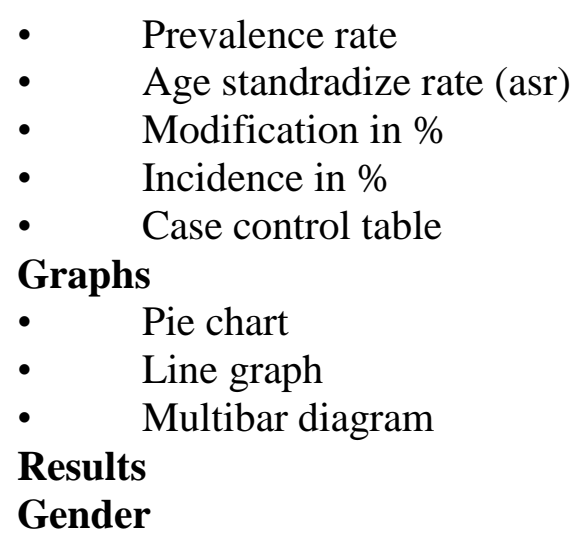

Hepatic disease was found predominance among guys and not in females. Pakistan as well as Worldwide showed elevated predominance, frequency as well as mortality level of hepatic malignant growth in guys than females. Utilization of measurable apparatuses additionally showed same outcomes among Pakistan and Worldwide [12].

\section{Around the world}

Incidence, occurrence as well as deaths. 3.5 times additional deaths of hepatic disease in guys as compared to females. Two point three times extra rate of liver malignant growth in guys as compared to females 2.6 times additional commonness of hepatic disease was in guys as compared to females.

\section{Pakistan}

Hepatic cancer in Pakistan was delineated. 2.2 times more prominent mortality of liver harm was in folks than females. 2.7 times more event of liver harmful development was showed up in folks than females. Five events more transcendence of liver ailment was seen in folks than females. [13, 14].

\section{Age}

The status of yearly passing rate among Pakistan plus World Health Organization criteria was portrayed by ages.

\section{Worldwide prevelance}

During 2012, worldwide had liver threat inescapability (3\%) in folks and (1\%) in females which rate was taken from each other malady. In around the globe, 2.6 events more normality of liver dangerous development in folks than females. Pakistan.

\section{Prevelance in Pakistan}

Pakistan had hepatic illness inescapability $(13.1 \%)$ in folks as well as $(1.6 \%)$ in females, which rate was taken from each and every other harmful development. Pakistan had five events extra incidence of hepatic ailment in males than females.

\section{Event in worldwide}

Globally hepatic threatening development event $(7.5 \%)$ for folks and $(3.4 \%)$ and for females from each other infection in 2012. In 2012, Cases of recurrence similarly as event ASR of liver threatening development was depicted around five territories of ecosphere (Asia, Africa, Europe, America, as well as Oceania) conversely with Pakistan. The most raised event ASR was found in Asia for folks (20) as well as for females (6.9), considering the way that it included countries like Japan as well as China (which had most critical recurrence of liver sickness). Europe had most negligible rate ASR (6.8) for folks as well as (2.2) for females. Pakistan yearly passing rate in accordance to age as well as sexual direction (per one lac people) was shown most vital top for females between seventy to seventy-four years age and for folks in eighty years age. The least passing rate had showed up in ten to nineteen years the two folks and female of Pakistan. In 2013, worldwide yearly passing rate as showed by age and sexual direction (for each one lac people) was shown by and large most raised top in age (80 years). Most diminished passing rate for folks flanked by five to nine years age as well as female flanked by 5 to 14 years age. [15].

\section{Prevalence in worldwide}

Globally hepatic threat inescapability (3\%) in folks and $(1 \%)$ in females which rate was taken from each other malady in 2012. In around the globe, 2.6 events more normality of liver dangerous development in folks than females. Pakistan. 


\section{Prevalence in Pakistan}

Pakistan had liver illness inescapability $(13.1 \%)$ in folks and $(1.6 \%)$ in females, which rate was taken from each and every other harmful development. Pakistan had five events more normality of hepatic ailment in folks than females.

In 2012, worldwide had liver threatening development event $(7.5 \%)$ for folks and (3.4\%) and for females from each other infection. In 2012, Cases of recurrence similarly as event ASR of liver threatening development was depicted around five territories of world (Asia, Africa, Europe, America, and Oceania) conversely with Pakistan. The most raised event ASR was found in Asia for folks (20) and for females (6.9), considering the way that it included countries like Japan and China (which had most critical recurrence of liver sickness). Europe had most negligible rate ASR (6.8) for folks as well as (2.2) for females. [16].

\section{Occurrence in Pakistan}

Pakistan had liver malignant growth frequency $(1.8 \%)$ for females and $(4.5 \%)$ for guys from all other disease in 2012. Pakistan had Incidence ASR for guys (4.7) and for females (2.5) in 2012.

\section{Mortality in worldwide}

Liver malignant growth had death rate just as mortality ASR of five locale of world (Asia, Africa, Europe, America, and Oceania) in contrast with Pakistan in 2012. The most elevated mortality ASR was found in Asia for guys (18.9) and for females (6.6), in light of the fact that it included nations like Japan and China (which had most elevated frequency of liver malignancy). Europe had least mortality ASR (6.1) for guys and (2.2) for females. Status of liver malignant growth because of death rate had portrayed among each of the five locals of world (Asia, Africa, Europe, America, and Australasia) in contrast with
Pakistan in 2013. Europe had most noteworthy mortality mean for by and large $10.7 \pm 3.8$, for females $7.1 \pm 2.33$ and for guys 14.6 \pm 5.9. America had most minimal mortality mean for generally $5.2 \pm 1.39$, for female $4.6 \pm 1.36$ and for guys $5.8 \pm 1.74$. The other three mainland's lie in the middle of them. America had most noteworthy mortality change from 1990 to 2013 in the two guys and females. Europe had the most elevated middle both in male and female. The females of Asia had least middle and guys of Africa had most reduced median. In 2012, worldwide had liver malignant growth mortality (11.2\%) for guys and, (6.3) for females from every single other disease.

\section{Asia}

In 2013 report, the most elevated mortality looked for in East Asia which had mortality

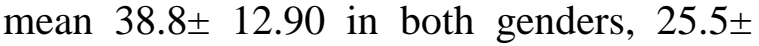
13.47 in females and 52.3 \pm 12.78 in guys and Central Asia had least mortality mean $3.0 \pm 2.62$ in both genders, 2.4 \pm 1.94 in females and 3.6 \pm 3.51 in guys. In East Asia, most elevated death rate had looked for in Mongolia for the two guys and females, and least looked for in china. In South Asia, Bangladesh had most elevated death rate and Sri Lanka had least death rate. Pakistan positioned third in death pace of South Asia and fourteenth of in general Asia. In Western Asia, most elevated passing was found in Kazakhstan and least in Uzbekistan of western Asia. In Central Asia, Georgia positioned first which had death rate for generally speaking 11.4 , for females $8.4 \%$ and for men 14.9\%. Joined Arab Emirates (U.A.E) had most reduced death rate. In Asia, East Asia had most noteworthy mortality middle 22.2 for females and 50.3 for guys. The Central Asia had most reduced mortality middle two for females and 2.6 for guys. This was portrayed in (Table 1a \& b). [17, 18]. 
Table 1a. Impact of liver cancer in Asia annual mortality rate (100,000 people)

\begin{tabular}{|c|c|c|c|c|c|c|c|}
\hline Country name & $\begin{array}{c}\text { Both } \\
\text { sexes }\end{array}$ & Female & Male & $\begin{array}{c}\text { Country } \\
\text { name }\end{array}$ & $\begin{array}{c}\text { Both } \\
\text { sexes }\end{array}$ & Female & Male \\
\hline South Asia & & & & East Aisa & & & \\
\hline Pakistan & $\mathbf{4 . 1}$ & $\mathbf{3 . 4}$ & $\mathbf{4 . 7}$ & Taiwan & $\mathbf{3 9 . 8}$ & $\mathbf{2 4 . 1}$ & $\mathbf{5 5 . 6}$ \\
\hline Bangladesh & $\mathbf{1 2 . 9}$ & $\mathbf{9 . 1}$ & $\mathbf{1 6 . 7}$ & Japan & 36.1 & 22.2 & 50.8 \\
\hline Maldives & 1.4 & $\mathbf{0 . 4}$ & 2.4 & China & $\mathbf{2 5 . 7}$ & $\mathbf{1 3 . 3}$ & $\mathbf{3 7 . 2}$ \\
\hline India & 5.3 & 4.3 & 6.3 & South Korea & 34.2 & 18.2 & 50.3 \\
\hline Bhutan & 3.4 & 2.0 & 4.6 & Mongolia & $\mathbf{6 6 . 4}$ & $\mathbf{5 4 . 6}$ & $\mathbf{7 8 . 4}$ \\
\hline Afghanistan & 3.1 & 3.2 & 3.0 & North Korea & 36.5 & 25.9 & 47.6 \\
\hline Sri Lanka & $\mathbf{1 . 3}$ & 0.8 & $\mathbf{1 . 7}$ & Thailand & 33.2 & 20.2 & 46.6 \\
\hline Nepal & 2.8 & 1.9 & 3.7 & & & & \\
\hline Mean & 4.3 & 3.1 & 5.4 & Mean & $\mathbf{3 8 . 8}$ & $\mathbf{2 5 . 5}$ & $\mathbf{5 2 . 3}$ \\
\hline S.D & 3.72 & 2.74 & 4.79 & S.D & 12.90 & 13.47 & 12.78 \\
\hline Median & 3.25 & 2.6 & 4.15 & Median & 36.1 & 22.2 & 50.3 \\
\hline
\end{tabular}

Table 1b. Impact of liver cancer in Asia annual mortality rate (100,000 people)

\begin{tabular}{|c|c|c|c|c|c|c|c|}
\hline Central Asia & & & & $\begin{array}{c}\text { Western } \\
\text { Asia }\end{array}$ & & & \\
\hline U.A.E & $\mathbf{1 . 0}$ & $\mathbf{0 . 7}$ & $\mathbf{1 . 1}$ & Turkmenistan & 5.5 & 4.2 & 6.8 \\
\hline Iran & 2.4 & 1.9 & 3.0 & Kyrgyzstan & 5.0 & 3.9 & 6.1 \\
\hline Iraq & 3.2 & 3.5 & 2.8 & Kazakhstan & $\mathbf{7 . 6}$ & $\mathbf{5 . 9}$ & $\mathbf{9 . 4}$ \\
\hline Palestine & 2.9 & 2.5 & 3.4 & Uzbekistan & $\mathbf{3 . 4}$ & $\mathbf{2 . 9}$ & $\mathbf{3 . 9}$ \\
\hline Israel & 3.7 & 2.9 & 4.5 & & & & \\
\hline Yemen & 2.3 & 2.1 & 2.4 & & & & \\
\hline Kuwait & 1.8 & 1.1 & 2.3 & & & & \\
\hline Turkey & 4.5 & 3.1 & 6.0 & & & & \\
\hline Oman & 2.0 & 1.4 & 2.3 & & & & \\
\hline Jordan & 1.2 & 0.9 & 1.4 & & & & \\
\hline Qatar & 1.4 & 1.3 & 1.4 & & & & \\
\hline Syria & 1.3 & 1.1 & 1.4 & & & & \\
\hline Georgia & $\mathbf{1 1 . 4}$ & $\mathbf{8 . 4}$ & $\mathbf{1 4 . 9}$ & & & & \\
\hline Mean & $\mathbf{3 . 0}$ & $\mathbf{2 . 4}$ & $\mathbf{3 . 6}$ & Mean & 5.1 & 4.0 & 6.2 \\
\hline S.D & 2.62 & 1.94 & 3.51 & S.D & 1.60 & 1.1 & 2.06 \\
\hline Median & 2.35 & 2.0 & 2.6 & Median & 5.0 & 3.9 & 6.1 \\
\hline
\end{tabular}

In 2013, Pakistan positioned third in death pace of South Asia locale and Ranked 14 in by and large Asia. In 2012, Pakistan had mortality ASR (2.5) for females and (4.5) for guys. Pakistan had death rate (3.4) and change looked for (46\%) for females in 2013.
Pakistan had death rate (4.7) and change looked for $(23 \%)$ for guys. This was depicted in (Table 2a-e). Pakistan had liver malignant growth mortality $(5.5 \%)$ for guys and $(2.7 \%)$ for females, from every single other disease in 2012. 
Table 2a. Liver cancer impact in Pakistan, in comparison to other location in Asia (mortality per $100,000 \&$ change from $1990-2013$ )

\begin{tabular}{|c|c|c|c|c|c|c|}
\hline \multirow{2}{*}{ Location } & \multicolumn{2}{c|}{ Both Sexes } & \multicolumn{2}{c|}{ Female } & \multicolumn{2}{c|}{ Male } \\
\cline { 2 - 7 } & Mortality & Change & Mortality & Change & Mortality & Change \\
\hline \multicolumn{7}{|c|}{ Eastern Asia } \\
\hline South korea & 34.2 & $78 \%$ & 18.2 & $80 \%$ & 50.3 & $78 \%$ \\
\hline Japan & $\mathbf{3 6 . 1}$ & $51 \%$ & $\mathbf{2 2 . 2}$ & $64 \%$ & $\mathbf{5 0 . 8}$ & $47 \%$ \\
\hline \multicolumn{7}{|c|}{ Southern Asia } \\
\hline Pakistan & $\mathbf{4 . 1}$ & $\mathbf{3 1 \%}$ & $\mathbf{3 . 4}$ & $\mathbf{4 6 \%}$ & $\mathbf{4 . 7}$ & $\mathbf{2 3 \%}$ \\
\hline India & 5.3 & $31 \%$ & 4.3 & $25 \%$ & 6.3 & $35 \%$ \\
\hline Nepal & 2.8 & $70 \%$ & 1.9 & $68 \%$ & 3.7 & $75 \%$ \\
\hline Afghanistan & 3.1 & $\mathbf{1 0 1 \%}$ & 3.2 & $\mathbf{9 1 \%}$ & 3.0 & $\mathbf{1 1 2 \%}$ \\
\hline Bangladesh & 12.9 & $43 \%$ & 9.1 & $20 \%$ & 16.7 & $60 \%$ \\
\hline Bhutan & 3.4 & $60 \%$ & 2.0 & $54 \%$ & 4.6 & $59 \%$ \\
\hline \multicolumn{7}{|c|}{ Central Asia } \\
\hline Iran & $\mathbf{2 . 4}$ & $34 \%$ & 1.9 & $34 \%$ & 3 & $35 \%$ \\
\hline Iraq & 3.2 & $\mathbf{2 \%}$ & 3.5 & $5 \%$ & $\mathbf{2 . 8}$ & $\mathbf{- 2 \%}$ \\
\hline Saudi Arabia & 2.6 & $26 \%$ & 2.6 & $75 \%$ & 3.6 & $8 \%$ \\
\hline \multicolumn{7}{|c|}{ South East Asia } \\
\hline Brunei & 5 & $42 \%$ & $\mathbf{1 . 5}$ & $\mathbf{- 1 3 \%}$ & 8.3 & $64 \%$ \\
\hline Singapore & 12.6 & $67 \%$ & 6.9 & $78 \%$ & 18.4 & $66 \%$ \\
\hline Mean & 9.8 & $\mathbf{4 9 . 7 \%}$ & 6.2 & $\mathbf{4 8 . 2 \%}$ & 13.5 & $\mathbf{5 0 . 7 \%}$ \\
\hline S.D & 11.78 & 6.6 & & 17.18 & \\
\hline Median & 4.1 & 3.4 & & 4.7 & \\
\hline
\end{tabular}

Table 2b. Liver cancer impact in Pakistan, in comparison to other location in Europe (mortality per 100,000 \& change from 1990-2013)

\begin{tabular}{|c|c|c|c|c|c|c|}
\hline \multirow{2}{*}{ Location } & \multicolumn{2}{|c|}{ Both Sexes } & \multicolumn{2}{c|}{ Female } & Male \\
\cline { 2 - 7 } & Mortality & Change & Mortality & Change & Mortality & Change \\
\hline Pakistan & $\mathbf{4 . 1}$ & $\mathbf{3 1 \%}$ & $\mathbf{3 . 4}$ & $\mathbf{4 6 \%}$ & $\mathbf{4 . 7}$ & $\mathbf{2 3 \%}$ \\
\hline \multicolumn{7}{|c|}{ Eastern Europe } \\
\hline Turkey & $\mathbf{4 . 5}$ & $66 \%$ & $\mathbf{3 . 1}$ & $57 \%$ & $\mathbf{6}$ & $72 \%$ \\
\hline \multicolumn{7}{|c|}{ Western Europe } \\
\hline Italy & $\mathbf{1 8 . 7}$ & $38 \%$ & $\mathbf{1 1 . 6}$ & $19 \%$ & $\mathbf{2 6 . 2}$ & $49 \%$ \\
\hline Spain & 11.7 & $24 \%$ & 7.9 & $6 \%$ & 15.7 & $36 \%$ \\
\hline Austria & 10.7 & $46 \%$ & 6.7 & $33 \%$ & 14.8 & $52 \%$ \\
\hline Portugal & 8.3 & $53 \%$ & 5.4 & $20 \%$ & 11.4 & $76 \%$ \\
\hline \multicolumn{7}{|c|}{ Europian Union } \\
\hline Germany & 9.1 & $123 \%$ & 6.2 & $124 \%$ & 12.0 & $\mathbf{1 2 0 \%}$ \\
\hline France & 13.6 & $49 \%$ & 6.8 & $66 \%$ & 20.9 & $44 \%$ \\
\hline \multicolumn{7}{|c|}{ Central Europe } \\
\hline Hungry & 10.9 & $\mathbf{5 \%}$ & 8.5 & $\mathbf{2 \%}$ & 13.6 & $\mathbf{7 \%}$ \\
\hline Romania & 9.6 & $\mathbf{1 5 4 \%}$ & 8.1 & $\mathbf{2 6 2 \%}$ & 11.1 & $108 \%$ \\
\hline Mean & $\mathbf{1 0 . 7}$ & $62 \%$ & 7.1 & $65.4 \%$ & $\mathbf{1 4 . 6}$ & $62.6 \%$ \\
\hline S.D & 3.89 & \multicolumn{7}{|c|}{} \\
\hline Median & 10.7 & 2.33 & & 5.9 & 13.6 & \\
\hline
\end{tabular}


Table 2c. Liver cancer impact in Pakistan, in comparison to other location in America (mortality per 100,000 \& change from 1990-2013

\begin{tabular}{|c|c|c|c|c|c|c|}
\hline \multirow{2}{*}{ Location } & \multicolumn{2}{|c|}{ Both Sexes } & \multicolumn{2}{c|}{ Female } & \multicolumn{2}{c|}{ Male } \\
\cline { 2 - 7 } & Mortality & Change & Mortality & Location & Mortality & Change \\
\hline Pakistan & $\mathbf{4 . 1}$ & $\mathbf{3 1 \%}$ & $\mathbf{3 . 4}$ & $\mathbf{4 6 \%}$ & $\mathbf{4 . 7}$ & $\mathbf{2 3 \%}$ \\
\hline \multicolumn{7}{|c|}{ North America } \\
\hline United States & 6.2 & $69 \%$ & 4.2 & $65 \%$ & $\mathbf{8 . 2}$ & $70 \%$ \\
\hline Canada & 5.0 & $67 \%$ & 3.8 & $75 \%$ & 6.2 & $\mathbf{6 2 \%}$ \\
\hline \multicolumn{7}{|c|}{ South America } \\
\hline Brazil & 4.4 & $70 \%$ & 3.8 & $61 \%$ & 5.0 & $78 \%$ \\
\hline Paraguay & $\mathbf{2 . 3}$ & $\mathbf{1 1 2 3} \%$ & $\mathbf{2 . 3}$ & $\mathbf{9 0 1 \%}$ & $\mathbf{2 . 4}$ & $\mathbf{1 4 3 2 \%}$ \\
\hline \multicolumn{7}{|c|}{ Central America } \\
\hline Costa Rica & 5.7 & $81 \%$ & 4.7 & $79 \%$ & 6.7 & $82 \%$ \\
\hline Mexico & 5.4 & $\mathbf{5 8 \%}$ & 5.5 & $\mathbf{4 8 \%}$ & 5.3 & $69 \%$ \\
\hline Cuba & 6.2 & $544 \%$ & $\mathbf{6 . 4}$ & $549 \%$ & 6.0 & $538 \%$ \\
\hline $\begin{array}{c}\text { Dominican } \\
\text { Republic }\end{array}$ & $\mathbf{6 . 7}$ & $321 \%$ & 6.1 & $348 \%$ & 7.3 & $302 \%$ \\
\hline MEAN & $\mathbf{5 . 2}$ & $\mathbf{2 9 1 . 6 \%}$ & 4.6 & $\mathbf{2 6 5 . 7 \%}$ & $\mathbf{5 . 8}$ & $\mathbf{3 2 9 . 1 \%}$ \\
\hline S.D & 1.39 & & 1.36 & & 1.74 & \\
\hline Median & 5.5 & 4.45 & & 6.1 & \\
\hline
\end{tabular}

Table 2d. Liver cancer impact in Pakistan, in comparison to other location in Africa (mortality per 100,000 \& change from 1990-2013)

\begin{tabular}{|c|c|c|c|c|c|c|}
\hline \multirow{2}{*}{ Location } & Both Sexes & \multicolumn{2}{c|}{ Female } & \multicolumn{2}{c|}{ Male } \\
\cline { 2 - 7 } Pakistan & Mortality & Change & Mortality & Mortality & Change & Mortality \\
\hline \multicolumn{7}{|c|}{ Southern africa } \\
\hline Lesotho & $\mathbf{3 . 3}$ & $3 \%$ & $\mathbf{2 . 3}$ & $11 \%$ & 4.2 & $-2 \%$ \\
\hline South Africa & $\mathbf{3 . 6}$ & $\mathbf{- 2 3 \%}$ & 2.8 & $-4 \%$ & 4.5 & $\mathbf{- 3 2 \%}$ \\
\hline \multicolumn{7}{|c|}{ Northern africa } \\
\hline Libya & 3.8 & $47 \%$ & 3.4 & $\mathbf{4 0} \%$ & 4.1 & $44 \%$ \\
\hline \multicolumn{7}{|c|}{ Eastern Africa } \\
\hline Zimbabwe & 3.5 & $\mathbf{5 7 5 \%}$ & 2.8 & $\mathbf{5 4 5 \%}$ & 4.3 & $598 \%$ \\
\hline \multicolumn{7}{|c|}{ Central Africa } \\
\hline Gabon & 5.9 & $-9 \%$ & 5.4 & $-10 \%$ & 6.5 & $9 \%$ \\
\hline Congo & 4.1 & $-13 \%$ & 3.7 & $\mathbf{- 1 8 \%}$ & 4.6 & $-8 \%$ \\
\hline \multicolumn{7}{|c|}{ Western Africa } \\
\hline The Gambia & $\mathbf{2 5 . 4}$ & $5 \%$ & $\mathbf{1 3 . 9}$ & $16 \%$ & $\mathbf{3 7 . 1}$ & $3 \%$ \\
\hline Guinea & 19.1 & $5 \%$ & 11.4 & $1 \%$ & 26.9 & $6 \%$ \\
\hline MEAN & 8.5 & $73.7 \%$ & 5.71 & $74.2 \%$ & 11.5 & $77.2 \%$ \\
\hline S.D & 8.63 & & 4.4 & & 12.95 & \\
\hline Median & 3.95 & & 3.55 & & 4.55 & \\
\hline
\end{tabular}


Table2e. Liver cancer impact in Pakistan, in comparison to other location in Australasia (mortality per 100,000 \& change from 1990-2013)

\begin{tabular}{|c|c|c|c|c|c|c|}
\hline \multirow{2}{*}{ Location } & \multicolumn{2}{|c|}{ Both Sexes } & \multicolumn{2}{c|}{ Female } & \multicolumn{2}{c|}{ Male } \\
\cline { 2 - 7 } & Mortality & Change & Mortality & Location & Mortality & Change \\
\hline Pakistan & $\mathbf{4 . 1}$ & $\mathbf{3 1 \%}$ & $\mathbf{3 . 4}$ & $\mathbf{4 6 \%}$ & $\mathbf{4 . 7}$ & $\mathbf{2 3 \%}$ \\
\hline Australia & $\mathbf{5 . 7}$ & $\mathbf{1 1 8 \%}$ & 4.1 & $\mathbf{1 8 0 \%}$ & $\mathbf{7 . 3}$ & $\mathbf{9 4 \%}$ \\
\hline New Zealand & $\mathbf{5 . 6}$ & $\mathbf{4 3 \%}$ & 4.1 & $\mathbf{2 9 \%}$ & $\mathbf{7 . 2}$ & $\mathbf{5 3 \%}$ \\
\hline Mean & 5.65 & $80.5 \%$ & $\mathbf{4 . 1}$ & $104.5 \%$ & 7.25 & 73.5 \\
\hline S.D & 0.07 & & 0.0 & & 0.07 & \\
\hline Median & 5.65 & & 4.1 & & 7.25 & \\
\hline
\end{tabular}

Hazard factor dependent mortality rate and change (1990-2013)

Liquor in worldwide

In 2013, worldwide had liver malignant growth death rate per one lac because of liquor. The most elevated death rate mean was appeared in Europe, for guys (2.6 \pm 1.37$)$ and for female $(1.1 \pm 0.48)$. The most reduced death rate mean was appeared in Australasia, for guys $(0.9 \pm 0.70)$ and for females $(0.3 \pm 0.23)$. The liver malignant growth mortality changes from 1990-2013 because of liquor. The most elevated change (increments) was appeared in America, for guys $33.1 \%$ and for females $62.7 \%$. The most reduced change (decline) was appeared in Europe, for guys -9.8 and for females$11.6 \%$.

\section{Liquor in Pakistan}

In 2013, Pakistan had demise rate (0.5) for folks and (0.2) for females. Pakistan had change (decay) for folks $-58 \%$ and for females $-59 \%$.

\section{Smoking in worldwide}

In 2013, Worldwide had liver harmful development passing rate per one lac on account of smoking. The most raised passing rate mean was showed up in Europe for folks (3.6 \pm 0.86$)$ and for female (0.4) among Asia, Europe and America with standard deviation $0.53,0.25$ as well as 0.37 independently. The most insignificant demise rate mean was showed up in Africa, for folks $(0.5 \pm 0.61)$ and for females $(0.03 \pm 0.05)$. The liver dangerous development mortality changes from 1990-
2013 in view of smoking. The most raised change (increase) was showed up in Asia, for folks $149.7 \%$ and in America, for females $229.8 \%$. The most insignificant change (increase) was showed up in Europe, for folks $38.3 \%$ and in Asia, for females72.2\%. [1921].

\section{Smoking in Pakistan}

In 2013, Pakistan had passing rate (0.7\%) for folks and (zero) for females. Pakistan had change (increase) for folks $45 \%$ and for female's $0 \%$.

\section{Meds in worldwide}

Worldwide had liver threatening development passing rate per one lac on account of prescriptions in 2013. The most raised passing rate mean was showed up in Europe, for folks $(2.5 \pm 1.60)$ and in Australasia, for female $(0.7 \pm 0.71)$. The most negligible passing rate mean was showed up in Africa, for folks $(0.3 \pm 0.19)$ as well as for females $(0.06 \pm 0.05)$. The liver illness mortality changes from 1990-2013 on account of meds. The most critical change (increase) was showed up in America, for folks $1491.7 \%$ and for females $1775.6 \%$. The most decreased change (increase) was showed up in Africa, for folks $642.3 \%$ as well as in Europe, for females $650.1 \%$.

\section{Drugs in Pakistan}

In 2013, Pakistan had demise rate (0.3) for folks and (0.1) for females. Pakistan had change (increase) for folks $483 \%$ and for females $585 \%$. 


\section{High sugar diet in world wide}

Worldwide had liver infection demise rate per one lac as a result of high sugar diet in 2013. The most critical demise rate mean was showed up in America, for folks (0.04 \pm 0.05$)$ and for female $(0.01 \pm 0.03)$. The general most diminished passing rate mean (zero) was showed up in all among Europe, Africa and Australasia. The most diminished change (increase) was showed up in Europe, for folks $64.2 \%$ and for females 58\% [21, 22].

\section{High sugar diet in Pakistan}

In 2013, Pakistan had by and large demise rate zero. Pakistan had change (increase), for folks $42 \%$ and for females $45 \%$.

\section{Exchange}

Different examinations on power of liver harmful development along its peril factors were done after the disclosure of liver sickness. IARC evaluated that exhaustively fourteen million occasions of ailments had ascended in 2012, in which the majority of cases for instance pretty much eight million, had been represented from monetarily making countries; encompassing $82 \%$ people of the world. Since non-melanoma skin dangerous developments can't be followed in ailment libraries, so this estimation excludes them). In 2012, liver ailment was the 6th most typically examined threatening development and the third driving explanation behind harm passing. Hepatocellular carcinoma was all around the 6th most progressive dangerous development (6\%) and the resulting driving explanation behind death (9\%).

In 2015 , it was realized 8,10500 passing. In which 263000 passing from liver dangerous development was a result of hepatitis B, 167000 to hepatitis C, and 245000 to alcohol. Folks were more much of the time affected with HCC than females. In Pakistan, World hepatitis day (28 May 2013) became seen as a liver most harmful developments day to draw overall energy on the overall prosperity risk coming about in light of "HCC". In
Pakistan occasion of HCC contrasts from $3.7 \%-16 \%$ of undermining tumors and most run of the mill goal of HCC changed into viral hepatitis $\mathrm{B}, \mathrm{C}$ and $\mathrm{D}$ related cirrhosis. In Pakistan, around $87 \%$ of HCC changed into on account of viral hepatitis both C (68\%) or B related cirrhosis $(22 \%)$ correspondingly another view from Hyderabad Sindh Pakistan had additionally shown high weight of viral related HCC (Hepatitis C $66 \%$ and hepatitis B 43\%) $[23,24]$.

The Department of Gastroenterology and Hepatology, Shaikh Zayed Hospital, Lahore among September 1994 and November 1996 have been evaluated look at of information on 76 patients admitted to the Shaikh Zayed Hospital. Mean age become $52.2 \pm 11.3$ years. $86 \%$ have been grown-up folks and $14 \%$ females. 86 rate sufferers had concealed cirrhosis recorded on ultrasound evaluation. $75 \%$ had been high bore for against HCV, $10 \%$ for $\mathrm{HBsAg}$ feasible, $10 \%$ for both HBsAg and antagonistic to $\mathrm{HCV}$ and 5\% cases had poor viral serology. Standard clinical limits were stomach torment, weight decrease, jaundice, growth of liver just as ascites. $43 \%$ sufferers were Child Pugh class $\mathrm{A}, 13 \%$ brilliance $\mathrm{B}$ and $13 \%$ brilliance $\mathrm{C}$ and $14 \%$ have been non-cirrhotic. Mean alfa fetoprotein levels had been $142 \pm 157 \mathrm{mg} / \mathrm{ml}$ (combination 2.7 to 1047). Assurance of hepatocellular carcinoma got developed in 60 sufferers by best in class needle objective biopsy under ultrasound steerage patients passed on after biopsy on account of wild kicking the bucket. $54 \%$ sufferers had solitary damage and $46 \%$ had multifocal or diffuse injuries. The typical size of sore got 70.8 , one centimeter. Around 20 sufferers procured inside sore alcohol imbuement. 54 degree of these with a tumor size sufferer got intra damage alcohol mixture. Tumor size's 54 level that is more noticeable than $8 \mathrm{~cm}$ kicked the can at some point or another of improvement. The noteworthy clarification of biggest organ (Liver) frustration among 8 
sufferers and risky depleting happened in 4 sufferers. Patients with a tumor length more than $8 \mathrm{~cm}$ had negative response towards inside injury alcohol immunization.

Current examination, inescapability of hepatic harm considered extra imperative to be number in folks as difference to females, together all around just as Pakistan. 2013 record, show status of yearly demise rate by ages caught among Pakistan with World wellbeing association basis portrays in order to, death speed for folks were tall in upper ages of eighty years

Raised passing rate in Pakistan was found in females age flanked by seventy to seventyfour yrs.' anyway in WHO was 80 years. Exhaustively, event age institutionalize rate just as death age institutionalize rate was generally essential in Asian just as African nations. All around, death rate was most significant as a result of alcohol usage anyway in Pakistan, due to meds utilization. Since Pakistan has limited alcohol, agreement to Islamic religion, Hepatitis B just as $\mathrm{C}$ were all the extra driving purpose behind hepatics threatening development in Pakistan [23, 24].

\section{Conclusion}

We came to the conclusion that incidence of hepatic carcinoma was higher in males rather than in females, mutually globally as well as Pakistan.

\section{Authors' contributions}

Conceived and designed the experiments: $\mathrm{M}$ Asad \& I Rasool, Performed the experiments: M Asad, I Rasool, S Khan \& F Anum, Analyzed the data: M Asad, I Rasool, S Khan, F Anum, MA Saleem \& S Raza, Contributed materials/ analysis/ tools: F Anum, MA Saleem \& S Raza, Wrote the paper: S Khan, F Anum, MA Saleem \& S Raza.

\section{References}

1. World Cancer Report (2014). World Health Organization. (2014). pp Chapter 5.6. ISBN 9283204298.
2. World Cancer Report (2014). World Health Organization. (2014). pp Chapter 1.1. ISBN 9283204298.

3. GBD 2015 Mortality and Causes of Death, Collaborators. (8 October 2016). Global, regional, and national life expectancy, all-cause mortality, and cause-specific mortality for 249 causes of death, 1980-2015: A systematic analysis for the Global Burden of Disease Study 2015. Lancet 388(10053): 1459-1544.

4. SEER Stat Fact Sheets (2016): Liver and Intrahepatic Bile Duct Cancer". NCI. Archived from the original on 2017-0728.

5. Hepato-Etymology. Dictionary.com. Archived from the original on 10 October 2015. Retrieved 24 October 2015.

6. Lobo DN \& Dileep N. (2009). Malignant tumors of the liver. Surgery 27(1): 30-37.

7. Parkin DM, Bray F, Ferlay J \& Pisani P (2002). Global cancer statistics. $C A$ Cancer J Clin 55: 74-108.

8. Emre S \& McKenna GJ (2004). Liver tumors in children. Pediatric Transplan 8(6): 632-8.

9. Plaats VD (2005). The Groningen hypothalamic liver perfusion system for improved preservation in organ transplantation. Physiology of the liver. By Abdelaziz Hussein Assistant Lecturer of Physiology.

10. Selby R, Kadry Z, Carr B, Tzakis A, Madariaga JR \& Iwatsuki S (1995). Liver transplantation for hepatocellular carcinoma. World J Surg 53-58.

11. Cong WM, Wu MC \& Chen H (1993) Clinical pathological features of small liver cancer: 93 case report. Chin J Oncol 372-374.

12. Chen H, Wu MC \& Zhou WP (1993). Reoperation of recurrent liver cancer 
experiences with 72 cases. $J$ Hepatobiliary Surg 5-8.

13. Ambrogelly A, Palioura S \& Söll D (2007). Natural expansion of the genetic code. Natu Chem Biol 29-35.

14. Ferlay J, Steliarova-Foucher E \& LortetTieulent J (2013). Cancer incidence and mortality patterns in Europe: Estimates for 40 countries in 2012. European Journal of Cancer 1374-1403.

15. Lozano R, Naghavi M, Foreman K, Lim S, Shibuya K \& Aboyans V (2012). Global and regional mortality from 235 causes of death for 20 age groups in 1990 and 2010: a systematic analysis for the Global Burden of Disease Study 2010. Lancet 2095- 128.

16. World Cancer Report (2014). International Agency for Research on Cancer, World Health Organization. ISBN 978-92-832-0432-9.

17. El-Serag HB \& Rudolph KL (2007). Hepatocellular carcinoma: epidemiology and molecular carcinogenesis. Gastroenterol 2557-2576.

18. Khan SA, Toledano MB \& TaylorRobinson SD (2008). Epidemiology, risk factors, and pathogenesis of cholangiocarcinoma. HPB 77-82.

19. Fitzmaurice, Christina MD (2017). Global Burden of Disease Liver Cancer Collaboration.

20. Wong M, Jiang Y \& Johnny (2016). International incidence and mortality trends of liver cancer: a global profile.

21. Bosch FX, Ribes J, Diaz M \& Cleries R (2004). Primary liver cancer: worldwide incidence and trends. Gastroenterol S5S16.

22. Parkash O \& Hamid S (2016) Department of Medicine, The Aga Khan University \& Hospital, Karachi): Next big threat for Pakistan Hepatocellular Carcinoma (HCC).

23. El-Serag HB (2002) Hepatocellular carcinoma: an epidemiologic view. $J$ Clin Gastroent S72-S78.

24. Butt AK, Khan AA \& Aslam A (1998). Predicting hospital mortality in cirrhotic patients: comparison of child-pugh and acute physiology, age and chronic health evaluation (APACHE III) scoring systems. Am J Gastroenterol 2469-2475. 